https://doi.org/10.15407/scine16.02.94

\author{
BOHDANOVYCH, V.Yu.', SYROTENKO, A.M. ${ }^{2}$, \\ PIEVTSOV, H.V. ${ }^{3}$, DOVHAN, O.D. ${ }^{4}$, and DUBLIAN, O.V. ${ }^{1}$ \\ 'Central Research Institute of the Armed Forces of Ukraine, \\ 28, Povitroflotskyi Ave., Kyiv, 03049, Ukraine, \\ +380 445201944 , cndi-admin@mil.gov.ua \\ ${ }^{2}$ National Defence University of Ukraine, \\ 28, Povitroflotskyi Ave., Kyiv, 03049, Ukraine, \\ +38044271 0697, info@nuou.org.ua \\ ${ }^{3}$ Ivan Kozhedub Kharkiv National Air Force University, \\ 77/79, Sumska St., Kharkiv, 61023, Ukraine, \\ +380 57 7049197, hnups@gmil.com \\ ${ }^{4}$ Scientific research Institute of informatics and law of the \\ National Academy of Law Sciences of Ukraine, \\ 3, P. Orlik St., Kyiv, 01024, Ukraine, \\ +380442349456, pravo@ippi.org.ua
}

\title{
METHOD OF INFORMATION AND TIMING SUPPORT OF GLOBAL, LOCAL SOCIO-POLITICAL AND OTHER PROCESSES IN THE CONTEMPORARY SECURITY ENVIRONMENT
}

Introduction. The information monitoring technologies in the security environment (SE), which are currently implemented in practical activity of the security and defense sector, are capable of detecting only hazards, threats, and some other destructive phenomena and factors that make it difficult to implement preventive measures to respond to the forecasted changes in $S E$.

Problem Statement. It is also very important to monitor the global and local processes, strategies of the leading states, trends in the development of the situation in certain regions in order to timely identify the threats, to assess their character, level, scale, and to forecast their dynamics and risks for defining areas of national security in the case of its implementation.

Purpose. The development of the method for information and timing support of global, local socio-political, and other processes in the contemporary security environment.

Materials and Methods. The method of information and timing support of global, local, and other processes (hereinafter referred to as "the Method") uses a set of analytical, logical, and other procedures with information obtained during the SE evaluation regarding destructive phenomena, events, threats, and conditions under which the national interests are realized within given time.

Results. The established procedures provide the comparison of the facts and events detected during the monitoring of SE, with global and local processes taken into account, which enables identifying the geopolitical

Citation: Bohdanovych, V.Yu., Syrotenko, A.M., Pievtsov, H.V., Dovhan, O.D., and Dublian, O.V. Method of Information and Timing Support of Global, Local Socio-Political and other Processes in the Contemporary Security Environment. Sci. innov. 2020. V. 16, no. 2. P. 94-99. https://doi.org/10.15407/scine16.02.94 
and other interests and intentions of other states, determining measures for information deception, information cover, various kinds of manipulations and psychological effect, and making managerial decisions in the system of ensuring national security on a timely basis.

Conclusions. The proposed method enables raising the efficiency of the implementation of the national interests, as it improves the information and analytical maintenance of the system of national security assurance. In particular, it makes it possible to identify the links between the active and covert actions of individual centers of power, neighboring states and competitors, and to provide sound recommendations on responses, in order to reduce risks in the key areas of national security to the military and political leadership of the state.

Keywords : information and timing support, security environment, global processes, local processes, threat, and national security.

Information security monitoring technologies implemented in the security and defense sector of Ukraine enable identifying only some dangers, threats, and other destructive phenomena and factors that cause them. In order to more effectively implement the national interests in the modern security environment, it is necessary to be able not only to identify these phenomena in a timely manner, but also to assess their nature, level, scale, to predict dynamics and possible losses in the key areas of national security, and to establish their links with global and local processes, strategies of leading countries, trends and tendencies of developments in particular regions where the state is pursuing its national interests, which opens the possibility for introducing preventive measures to respond to the forecast changes in the security environment.

The solution of this problem will make it possible to increase the efficiency and validity of managerial decisions regarding the realization of national interests in the key areas of national security in the face of modern threats of military and hybrid nature.

The Concept of the Development of the Security and Defense Sector of Ukraine approved by the President's Decree [1] defines a system of prospects for the development of Ukraine's security and defense capabilities in the medium term based on assessment of the security environment. At the same time, it identifies ways for building the national security and defense capacity that will guarantee Ukraine's peaceful future, as well as provide timely identification, prevention, and neutralization of external and internal threats to national security, guarantee of personal security, human and citizen constitutional rights and freedoms, formation of cybersecurity, rapid joint response to crisis and emergency situations, together with the security and defense sector of Ukraine. The practical implementation of these tasks foresees establishing an effective security and defense sector (SDS) management system, combining the operational capabilities of the SDS components, ensuring timely and adequate response to national security threats and rational use of public resources, and improving the SDS planning system [1]. However, the results of the security assessment presented in the Concept concern only individual threats, which complicates the qualitative resolution of other major tasks and does not allow predicting changes in the security environment.

Research [2] describes the concept of integrated use of military and non-military forces and means to create a sufficient level of military security of the state, which provides support for the realization of national interests, but does not contain recommendations on information and time support of global and local processes. It creates obstacles and threats at certain stages of the realization of national interests. However, there, there is only a passing mention of the need to implement information technologies compatible with the software of the Main Situation Center.

The current national security strategy [3] defines the need for improvement of the state strategic planning system, creation of a unified system for monitoring, analysis, forecast, and decision-making in the field of national security and defense, ensuring of effective coordination and operation of a unified system of situation centers of the relevant authorities of the Security and 
Defense System of Ukraine, which is the essence of innovative projects in the field of national security. However, it does not specify what information for implementation of these projects shall be derived from the security environment and what input data are required.

In view of the above, the purpose of this research is to develop a method for information and time support of global and local socio-political and other processes in modern security environment.

Raising the efficiency of the Security and Defense System of Ukraine can be achieved by introducing innovative information processing technologies and improving the information and analytical support of the Main Situation Center. For the effective implementation of the national interests of the state, it is necessary to identify threats and dangers in a timely manner, to assess their nature, level, scale, what global and local processes they generate or intensify, as well as to predict scenarios of their destructive impact in time and space, to preventively prepare favorable conditions for achieving the goals, that is, to analyze and to appropriately control changes in the security environment. Here, the security environment means geopolitical, political, diplomatic, military, economic, information and other spheres where there arise, exist, concentrate or manifest themselves favorable conditions or dangerous phenomena, potential and real threats to the national interests in which the state exercises its policy, interacts with international security structures, strategic partners, allies, military-political and other institutions and organizations for the sake of sustainable development, within a certain time period [4]. This approach to defining security environment not only identifies and assesses threats to the realization of national interests, but also provides additional information on global and local processes, strategies of leading countries, trends and tendencies in developments in individual regions and worldwide. As of today, the solution of these tasks in the system of formation of national security has not been organized in terms of legal framework, except for the monitoring of dangers and threats, which is one of the directions of strategic monitoring and a stage of the strategic planning in the field of national security [5]. However, the monitoring data by themselves are not enough to effectively ensure the implementation of national interests. More scrupulous analytical processing of information circulating in the security environment but not captured during the monitoring is required. Processing such information requires highly-skilled analysts and appropriate methodological tools with the proposed method of information and time support of global and local socio-political and other processes in modern security environment as their main component. The general structure of the method is shown in Fig. 1.

The essence of the method for information and time support of global, local, and other processes (hereinafter referred to as "the Method") is to use a set of analytical, logical, expert, comparative, and other procedures with the use of information obtained from the assessment of security environment with respect to destructive phenomena, events, threats, and conditions in which the implementation of national interests takes place within a certain time period. Taken together, these actions provide a comparison of facts and events identified while monitoring the security environment with global and local processes, which makes it possible to identify geopolitical and other interests, intentions of other states, misinformation, cover stories, various types of manipulations and psychological impacts, and thereby to make sound and timely managerial decisions in the national security system.

Information and time support involves the cyclical nature of information processing. The complete information processing cycle consists of 10 steps.

At the first and second stages, the security environment is evaluated using the technologies described in [2]. In the course of the evaluation, it is likely to identify and to record information on destructive phenomena, events, threats, and 


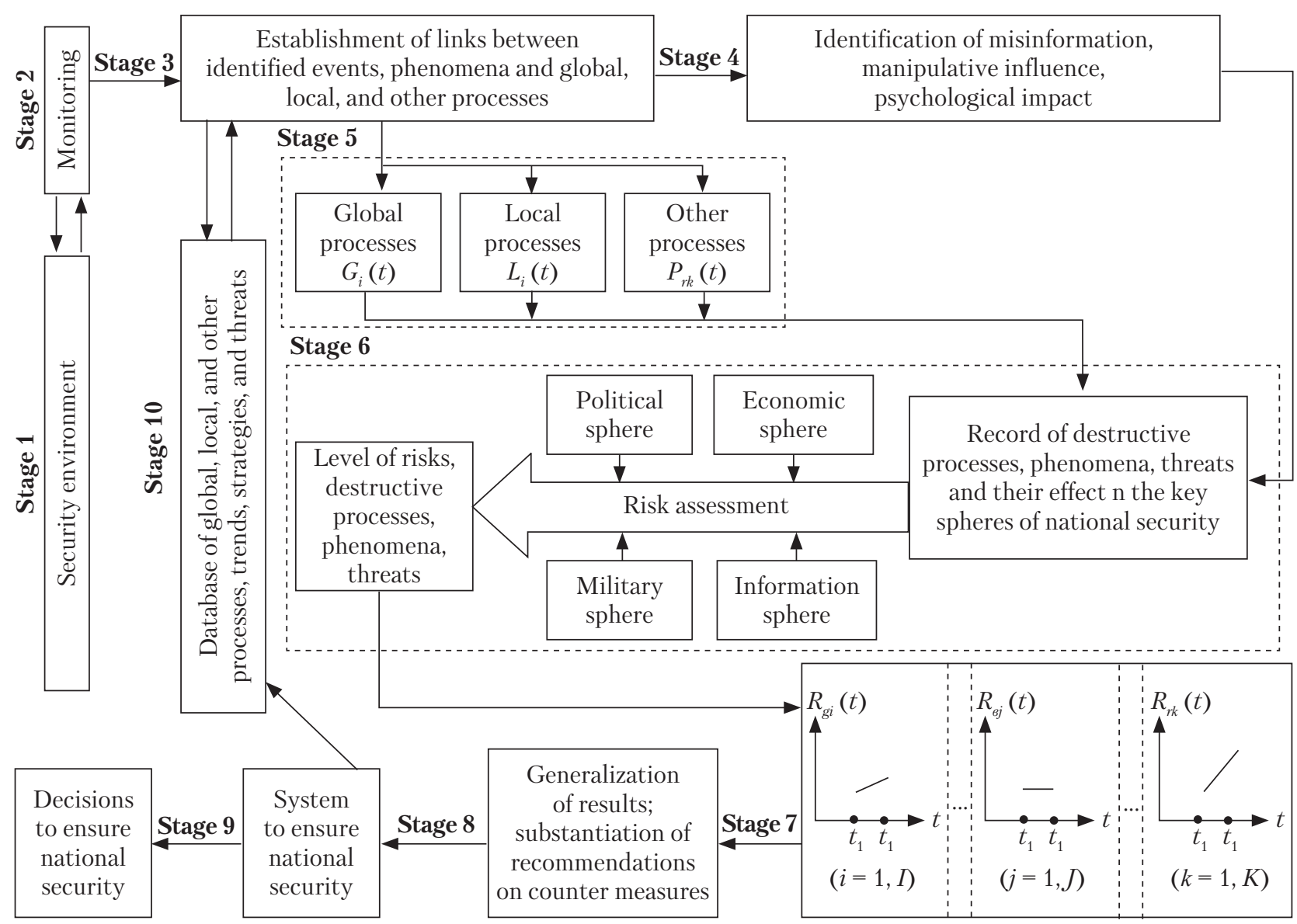

General Structure of the Method for Information and Time Support of Socio-Political Processes

conditions under which national interests are implemented within a certain time period.

At the third stage, based on the information obtained at the previous stages, its correlation with global, local, and other processes that directly or indirectly affect the implementation of national interests is assessed by experts [7]. As a rule, such processes are studied more deeply by the analytical units of the security and defense sector and are recorded in the relevant databases used at the stage 10 .

At the fourth stage, misinformation, manipulative influences, psychological impact, and cover stories of individual processes and phenomena are distinguished from the entire information flow. This process can be automated through the use of specialized information technology, computerized information security systems or the involvement of security and defense experts.

At the fifth stage, procedures for filtering information flows and assigning them to global, local, and other processes that have a destructive effect or complicate the implementation of national interests, firstly, the priority ones are performed, usually, with help of expert methods, as described in detail in [6].

At the sixth stage, each identified or updated process is linked to national security risks in the key areas: political, economic, military, information, etc. In this case, the Ishikawa method is the most appropriate [8]. In each area, the experts select the most informative indicators for assessing the impact on overall risk for a given area, which ultimately allows them to build a three- 
level hierarchy of integral risk assessment using the method of Saati hierarchy analysis realized in the model M7 described in detail in [4].

The experts for integral risk assessment shall be selected in such a way as to ensure that, firstly, they are experienced namely in these areas, secondly, for each area, 5-7 experts are necessary. The risk scale ranges from 0 to 1 , for each $i$-th $(i=1, I)$ global process $R_{g i}(t)$, each $j$-th $(j=1, J)$ local process $R_{l j}(t)$, and $k-x(k=1, K)$ other (initial or new, identified at the stage 5 ) process $R_{r k}(t)$.

At the seventh stage, the assessed risks are presented graphically, textually or in other way and their dynamics in time are recorded. An example of graphical presentation of risks and their dynamics for time $t_{1}$ and $t_{2}$ is given at the bottom of Fig. 1.

At the eighth stage, we summarize the results obtained for each of these processes: global, local, and others. There are many possible threats and destructive factors that can trigger each of these processes. For each process, an integral risk for the implementation of each priority national interest is formulated. Also, at this stage, recommendations for response to identified real and potential threats and destructive factors are substantiated, and threats and destructive factors that require urgent, medium-term, and long-term responses are grouped.

At the ninth stage, the capacity of the state to continue or to suspend the implementation of national interests, to organize both direct (symmetric) and asymmetric countermeasures to threats and destructive phenomena, as well as resources and other types of support are assessed.

At the last, tenth, stage, if necessary, the database of global, local, and other processes is adjusted, reporting materials are prepared and so on.

Thus, the proposed method of information and time support of global and local socio-political and other processes in modern security environment makes it possible to raise the effectiveness of implementation of national interests, as it improves the information-analytical service of the national security system, in particular, allows identifying links between active and hidden actions of individual key players, neighboring states, competitors and their strategic concepts regarding Ukraine, timely detecting and forecasting destructive factors and potential threats to priority national interests, as well as providing the military and political leaders with sound recommendations on responses in order to reduce risks in the key spheres of national security.

\section{REFERENCES}

1. The Decree of the President of Ukraine "On the decision of the National Security and Defense Council of Ukraine "On the Concept of Development of the Security and Defense Sector of Ukraine"” of 04.03.2016 no. 92/2016. URL: http:// zakon.rada.gov.ua./laws/show/92/2016 (Last accessed: 09.12.2019).

2. Bohdanovych, V. Yu., Romanchenko, I. S., Svyda, I. Yu., Syrotenko, A. M. (2019). Methodology of integrated use of military and non-military forces and means of the security and defense sector for counteracting modern threats to military security of Ukraine. Lviv [in Ukrainian].

3. The Decree of the President of Ukraine "On the decision of the National Security and Defense Council of Ukraine "On the Strategy of National Security of Ukraine”" of 06.05.2015 on. 287/2015. URL: http://zakon.rada.gov.ua./laws/ show/287/2015 (Last accessed: 09.12.2019).

4. Bohdanovych, V. Yu., Syrotenko, A. M., Pryma, A. M., Vovchanskyi, V. I. (2019). New "labyrinths" of security environment and their influence on the provision of military security of the state. Science and Technology of the Air Force of Ukraine, 2(35), 9-15 [in Ukrainian].

5. Bohdanovych, V.Yu., Svuda, I. Yu., Skulish Ye. D. (2012). Theoretical and methodological bases for ensuring the national security of Ukraine. Vol. 4: Military security of Ukraine and ways of its provision. Kyiv [in Ukrainian]. 
6. Bohdanovych, V. Yu., Svyda, I. Yu., Skulish Ye. D. (2012). Theoretical and methodological bases of ensuring national security of Ukraine: monohraph: $7 \mathrm{t}$. Vol. 1: Theoretical foundations, methods and technologies of ensuring national security of Ukraine. Kyiv [in Ukrainian].

7. Method Ischikawa Chart. 1952. URL: http: // www. inventech.ru/pub/methods/metod-0019 (Last accessed: 02.12.2019).

Received 10.09.19

Revised 17.12.19

Accepted 26.12.19

В.Ю. БОГДАНОВИЧ ${ }^{1}$, А.М. СИРОТЕНКО

Г.В. ПЕВЦОВ 3 О.Д. ДОВГАНЬ 4 , О.В. ДУБЛЯН ${ }^{1}$

${ }^{1}$ Центральний науково-дослідний інститут Збройних Сил України, просп. Повітрофлотський, 28, Київ, 03049, Україна,

+380 44520 1944, cndi-admin@mil.gov.ua

${ }^{2}$ Національний університет оборони України ім. Івана Черняховського, просп. Повітрофлотський, 28, Київ, 03049, Україна,

+380 44271 0697, info@nuou.org.ua

${ }^{3}$ Харківський національний університет Повітряних Сил імені Івана Кожедуба,

вул. Сумська, 77/79, Харків, 61023, Україна,

+380 57 7049197, hnups@gmil.com

${ }^{4}$ Науково-дослідний інститут інформатики і права

Національної Академії правових наук України,

вул. П. Орлика, 3, Київ, 01024, Україна,

+380 442349456 , pravo@ippi.org.ua

МЕТОД ІНФОРМАЦЙНО-ЧАСОВОГО СУПРОВОДЖЕННЯ ГЛОБАЛЬНИХ, ЛОКАЛЬНИХ СОЦІАЛЬНО-ПОЛІТИЧНИХ ТА ІНШИХ ПРОЦЕСІВ У СУЧАСНОМУ БЕЗПЕКОВОМУ СЕРЕДОВИЩІ

Вступ. Реалізовані на сьогодні у практиці діяльності сектору безпеки й оборони інформаційні технології моніторингу безпекового середовища (БС) дозволяють виявляти лише деякі небезпеки, загрози та інші деструктивні явища та фактори, що ускладнює впровадження превентивних заходів щодо реагування на прогнозовані зміни БС.

Проблематика. Для своєчасного виявлення загроз, оцінювання їх характеру, рівня, масштабу та прогнозування їхньої динаміки та ризиків у разі реалізації для визначальних сфер національної безпеки дуже важливо відстежувати глобальні та локальні процеси, стратегії провідних держав, тенденції та тренди розвитку ситуацій у окремих регіонах.

Мета. Розробка методу інформаційно-часового супроводження глобальних, локальних соціально-по ᄀлі-тичних й інших процесів у сучасному БС.

Матеріали й методи. Використання низки аналітичних, логічних та інших процедур з інформацією, отримуваною в ході оцінювання БС стосовно деструктивних явищ, подій, загроз, а також умов, у яких відбувається імплементація національних інтересів, на обраному часовому інтервалі.

Результати. Використання методу забезпечує співставлення фактів, подій, виявлених в ході моніторингу БС, 3 глобальними й локальними процесами, що дає змогу ідентифікувати геополітичні та інші інтереси, наміри інших держав, вчасно виявляти заходи щодо дезінформації, інформаційного прикриття, різних маніпуляцій і психологічного впливу та своєчасно приймати управлінські рішення в системі забезпечення національ $\neg$ ної безпеки.

Висновки. Запропонований метод дає змогу підвищити ефективність імплементації національних інтересів держави, оскільки покращує інформаційно-аналітичне обслуговування системи забезпечення національної безпеки, зокрема дозволяє виявляти зв'язки між активними та прихованими діями окремих центрів сили, сусідніх держав та конкурентів, надавати воєнно-політичному керівництву держави обгрунтовані рекомендації щодо реагування 3 метою зниження ризиків у визначальних сферах національної безпеки.

Ключові слова: інформаційно-часовий супровід, безпекове середовище, глобальні процеси, локальні процеси, загроза, національна безпека. 